\title{
DIGITÁLNA EKONOMIKA, DIGITÁLNE SLUŽBY A DAŇ Z DIGITÁLNYCH SLUŽIEB - HROZBA ALEBO VÝZVA PRE NORMOTVORCOV ${ }^{1}$
}

\section{DIGITAL ECONOMY, DIGITAL SERVICES AND DIGITAL SERVICES TAX - THREAT OR CHALLENGE FOR LEGISLATORS?}

\author{
Ladislav Hrabčák, Monika Stojáková \\ Univerzita Pavla Jozefa Šafárika v Košiciach, Právnická fakulta \\ https://doi.org/10.33542/SIC2020-1-02 \\ „Digitálne hospodárstvo je výzvou pre naše daño- \\ vé systémy. Najdôležitejšie je, že v diskusii sa po- \\ tvrdilo želanie všetkých lídrov d'alej pracovat' na \\ efektívnom a spravodlivom riešení." \\ Donald Tusk, predseda Európskej rady, po stret- \\ nutí s lídrami EÚ v marci 2018
}

\begin{abstract}
ABSTRAKT
Autori sa v predmetnom článku zaoberajú problematikou digitálnej ekonomiky a otázkami s tým súvisiacimi. Centrálnu pozornost' venujú otázke digitálnych služieb, ako jedným z javov digitálnej ekonomiky, a taktiež ich zdaňovaniu. Právne poriadky viacerých štátov už regulujú určité parciálne otázky digitálnej ekonomiky ako napriklad zdaňovanie digitálnych platforiem či zdaňovanie virtuálnych mien, no v súčasnosti možno badat' aj tendencie zdaňovat' digitálne služby. V príspevku sú načrtnuté návrhy právnych úprav na medzinárodnej (vrátane európskej) úrovni a na úrovni národných parlamentov. Niektoré štáty už majú prvotné skúsenosti so zdaňovaním tzv. ,,digitálnych gigantov“, a preto je možné zhodnotit, aké riešenie by bolo $z$ hl'adiska zdaňovania najideálnejšim. Aj na túto otázku sa autori pokúsia poskytnút'odpoved' $v$ nasledujúcom texte.
\end{abstract}

\begin{abstract}
The authors deal in this article with the issue of digital economy and related issues. It pays central attention to the issue of digital services as one of the phenomena of the digital economy, as well as their taxation. The laws of several states already regulate certain partial issues of the digital economy, such as taxation of digital platforms or taxation of virtual currencies, but at present there are also tendencies to tax digital services. The paper outlines legislative proposals at international (including European) and national parliaments level. Some countries already have initial experience in taxation of "digital giants" and therefore it is possible to assess what solution would be most appropriate in terms of taxation. The authors will also try to answer this question in the following text.
\end{abstract}

\footnotetext{
Tento príspevok vznikol ako čiastkový výstup riešenia projektu vvgs-2019-1068 „,Blockchain technológia ako činitel’ ovplyvňujúci súčasnú podobu práva“.
} 


\section{I. ÚVOD}

Pre dobu 21. storočia je príznačná globalizácia, ktorá preniká do všetkých oblastí l'udského života. Právo a ekonomika v tomto ohl'ade nie sú žiadnou výnimkou. Spolu s prudkým technologickým pokrokom, tak prinášajú viaceré otázky, s ktorými je potrebné sa vysporiadat'. V súčasnosti sa možno čoraz väčšmi postretnút' s tzv. digitálnymi javmi, ktoré prináša digitálna ekonomika.

Máme za to, že digitálne javy vo všeobecnosti patria medzi nový fenomén, s ktorým sa musí vysporiadat' aj veda o daňovom práve. ${ }^{2}$ Vystávajú tu $\mathrm{z}$ daňovo - právneho hladiska viaceré otázky, no najmä tá, či tieto digitálne javy sa majú vôbec zdaňovat' a ak áno, aké bude optimálne riešenie ich zdaňovania, aby nedochádzalo ku disproporciám na poli jednotného vnútorného trhu, pokial” ide o členské štáty Európskej únie (d’alej aj ako „EU'“).

V tejto súvislosti je potrebné poukázat' na ustálenú kategorizáciu štátov, ktorá sa využíva od obdobia studenej vojny, a to na:

1. rozvinuté krajiny - patria tu členské štáty Organizácie pre hospodársku spoluprácu a rozvoj (d'alej aj ako „,OECD“), vrátane tých členských štátov EÚ, ktoré nie sú zároveň aj členmi OECD a iné štáty (napr. Andora a pod.),

2. krajiny s transformujúcou sa ekonomikou - radíme sem najmä krajiny juho - východnej Európy,

3. rozvojové krajiny - sem patria tie štáty, ktoré nemožno zaradit' do žiadnej z predchádzajúcich kategórií.

Túto klasifikáciu štátov uvádzame účelovo, a to z toho dôvodu, že chceme tým poukázat', že medzi štátmi existujú priepastné rozdiely po stránkach ako sú nízke HDP na obyvatel'a, vysoká úmrtnost', nízky index l’udského rozvoja a iné, a to už po dlhé obdobie. Tieto rozdiely sa medzi štátmi úplne nestierajú, ba naopak, možno hovorit’ o ich prehlbovaní. Spomínané digitálne javy môžu k nerovnostiam prispiet'. Za súčasného stavu možno konštatovat', že digitálna ekonomika prináša výhody len určitým skupinám štátov, medzinárodným korporáciám a jednotlivcom.

Digitálna ekonomika a javy, ktoré so sebou prináša, predstavujú vel'ké výzvy. Aj v danej oblasti možno vidiet', že zdaňovanie, resp. dane môžu slúžit' aj ako nástroj na dosahovanie iných ciel'ov (v tomto prípade napríklad deklarované stieranie rozdielov medzi podnikatel'mi (vid' nižšie)) ako len uspokojovanie fiskálnych záujmov štátu, či obcí. V prípade, ak sa štáty rozhodnú zdaňovat' vybrané digitálne javy, je nutné sa zamysliet', či bude postačovat' riešenie na národnej úrovni alebo je potrebný spoločný a koordinovaný prístup na medzinárodnom fóre.

Ciel’om predmetného príspevku je rozanalyzovat' vybrané aspekty digitálnej ekonomiky, a to najmä zdaňovanie digitálnych služieb a načrtnút' možné d'alšie tendencie smerom do budúcna za súčasného overenia nastolených hypotéz.

V rámci predmetného príspevku sa pokúsime overit' hypotézu, či sa digitálne služby majú zdaňovat'. Ak bude potvrdená uvedená hypotéza, budeme pokračovat' overením čiastkových hypotéz:

- Na zdaňovanie digitálnych služieb postačujú existujúce nástroje zdaňovania.

- Na zdaňovanie digitálnych služieb je potrebné zaviest' nové dane.

V prípade kladného overenia druhej čiastkovej hypotézy, overíme nasledujúce parciálne hypotézy:

2 Bližšie: napr. BABČÁK, V. Daňové právo na Slovensku. 1. vydanie. Bratislava: EPOS, 2015. s. 149 a nasl. 
- Pri zavádzaní nových daní z digitálnych služieb je potrebné nájst' medzinárodný, či európsky model zdaňovania.

- Zdaňovanie digitálnych služieb je potrebné ponechat' v daňovej suverenite štátov.

Za účelom naplnenia vytýčeného ciel'a sme využili viaceré metódy ako analýza, syntéza, dedukcia, komparácia, metóda historická a pod., ktorých kombináciou možno dosiahnut' synergický efekt.

\section{DIGITÁLNA EKONOMIKA}

\section{Pojem a podstata digitálnej ekonomiky}

Jedným z ústredných pojmov tohto príspevku je tzv. digitálna ekonomika. Tá v podstate predstavuje akúsi podkategóriu ekonomiky samotnej. Digitálna ekonomika „...súvisí s rýchlym nástupom a prenikaním informačných a komunikačných technológii do všetkých oblastí l'udskej činnosti, čo vyžaduje i nové pohl'ady na faktory ovplyvňujúce vývoj a úspešnost' ekonomiky. “"

Rozvoj digitálnej ekonomiky je úzko spojený s nárastom objemu digitálnych dát. Podl’a správy Organizácie spojených národov (d’alej aj ako „OSN“) nazvanej „Digital Economy Report 2019" došlo k nárastu objemu dát zo $100 \mathrm{~GB} /$ deň v roku 1992 na viac ako 45000 $\mathrm{GB} /$ sekunda v roku 2017. Objem dát do roku 2022 by sa mal vyšplhat' až na 150700 $\mathrm{GB} /$ sekunda. $^{4} \mathrm{Na}$ uvedených faktoch teda vidíme, že význam digitálnej ekonomiky vzrastá.

To súvisí s čoraz väčším uplatňovaním podnikatel'ského modelu označovaného ako „datadriven business model“". Ten využívajú tzv. digitálne platformy, ktorých podstatu rozoberieme v texte nižšie. Silu tohto podnikatel'ského modelu možno demonštrovat' na tom, že ho využívajú, resp. uplatňujú až $7 \mathrm{z}$ top 8 svetových spoločností. ${ }^{5}$

Vo všeobecnosti platí, že digitálne dáta môžu byt' využité na riešenie určitých sociálnych problémov a pre rozvoj. Z podnikatel'ského pohl'adu je zjavnou výhodou zvyšovanie produkcie tovarov a služieb, ich vyššia kvalita a taktiež znižovanie produkčných nákladov. Je nutné taktiež dodat', že digitálna ekonomika sa dotkne aj tých subjektov (najmä podnikatel'ských), u ktorých sa na prvý pohl'ad zdá, že s ňou nemajú nič spoločné.

Okrem výhod prináša so sebou digitálna ekonomika aj nevýhody, ktoré sa môžu prejavit' $\mathrm{v}$ rôznej podobe. Jednou z nich je automatizácia výrobných procesov. Zo strany podnikatel'a nemožno brat' automatizáciu za nevýhodu, ale zo strany zamestnancov to môže znamenat' prípadnú stratu zamestnania z dôvodu nadbytočnosti. Ďalšou z nevýhod sú aj vyššie nároky na kvalifikáciu zamestnancov. Tí budú musiet' mat' vyššiu znalost' v oblasti informačných technológií.

$\mathrm{Na}$ všetky tieto problémy bude potrebné nájst' aj riešenie v právnej rovine. Je preto určitou výzvou pre normotvorcov zvládnut' vzniknutú situáciu, pretože technologický pokrok preskočil stav právny o niekol'ko dekád. Tie výzvy nemajú len daňovo - právny rozmer, ktorému budeme venovat' centrum svojej pozornosti, ale aj rozmer pracovnoprávny, občianskoprávny a pod. V d'alšom texte obmedzíme svoj výklad na otázku zdaňovania digitálnych služieb v digitálnej ekonomike.

PAPULA, J. a kol. Manažérska ekonomika. 1. vydanie. Bratislava: Wolters Kluwer, 2017. s. 22.

United Nation: Digital Economy Report 2019 z júla 2019. s. 2. [online]. [cit. 11-12-2019]. Dostupné na:

https://unctad.org/en/PublicationsLibrary/der2019_overview_en.pdf.

5 Tamtiež, s. 2. 


\section{DIGITÁLNE SLUŽBY A ICH ZDAŇOVANIE}

\section{Všeobecné východiská zdaňovania digitálnych služieb}

Moderné technológie v rámci digitálnej ekonomiky predstavujú vel'ké výzvy pre daňové správy štátov, čo sa týka zvýšenia efektivity správy daní, zjednodušenia medzinárodnej spolupráce a môžu prispiet' aj k znižovaniu počtu daňových únikov. ${ }^{6}$ Digitalizácia však predstavuje aj akýsi materiálny prameň práva, ktorý vyvoláva potrebu zmien vo formálnych prameňoch práva. Ide o jeden z javov, ktoré ,....spôsobujú, že právo je také, aké je a o javy, ktoré sú späté s vývojovými etapami ponímania práva. " ${ }^{7}$ Existujúce daňovo - právne predpisy obsahujú v súčasnosti už nepostačujúce pravidlá, čo platí najmä o úprave zdaňovania príjmov právnických osôb.

Pojem digitálna služba a jeho vymedzenie je imanentnou súčast'ou navrhovaných právnych úprav či už na úrovni medzinárodnej alebo na úrovni jednotlivých štátov, i ked' je nutné konštatovat', že návrhy unilaterálnych úprav vychádzali vo vel'kej miere z návrhov medzinárodných organizácií, čo sa prejavilo aj pri vymedzení využívaného pojmoslovia. Z teoretického hl'adiska tak možno uvažovat' o dvoch rovinách chápania pojmu digitálna služba, a to:

- v užšom slova zmysle - ide o stotožňovanie pojmu digitálna služba a digitálna reklama, a

- $\quad$ v širšom slova zmysle - tu je možné vychádzat' z návrhu smernice Rady (EÚ), ktorou sa stanovujú pravidlá týkajúce sa zdaňovania príjmov právnických osôb, ktoré sa vyznačujú významnou digitálnou prítomnost'ou $\{\operatorname{SWD}(2018) 81$ final $\}-\{\operatorname{SWD}(2018) 82$ final $\}$ zo dňa 21.03.2018 (d’alej aj ako „návrh smernice DST“), podl'a ktorého digitálnymi služba$\mathrm{mi}$, ,...sú služby poskytované cez internet alebo elektronickú siet', ktorých poskytovanie je z dôvodu ich povahy z vel'kej časti automatizované s minimálnym l’udským zásahom, pričom je nemožné ho zabezpečit’ bez informačnej technológie... " ${ }^{8}$, pričom obsahuje aj exemplifikatívny výpočet služieb, ktoré sa radia pod predmetný pojem (napr. poskytnutie digitalizovaných produktov vo všeobecnosti vrátane softvéru a jeho modifikácií alebo inovácií, služby poskytujúcich alebo podporujúcich prítomnost' podnikov alebo jednotlivcov v elektronickej sieti, ako aj webová lokalita alebo webová stránka, služby automaticky generovaných počítačom cez internet alebo elektronickú siet' ako reakcia na špecifické údaje, ktoré zadá odberatel' a pod.).

Hlavnou snahou legislatívcov je to, aby sa zisky právnických osôb zdaňovali tam, kde sa hodnota skutočne vytvára. Podl'a nášho názoru tu dochádza aj $\mathrm{k}$ ustáleniu nového princípu zdaňovania medzi už etablované a tradičné princípy. ${ }^{9}$

Pravidlá zdaňovania príjmov právnických osôb sú založené v prevažnej miere na fyzickej prítomnosti v tej - ktorej krajine. Z toho vyplýva, že sa nezohl'adňuje hodnota, ktorá bola vytvorená účast'ou používatel'ov v danej jurisdikcii. ${ }^{10}$

Ide o vel'mi aktuálnu otázku, ktorá predbehla právny stav o niekol'ko rokov. To si štáty uvedomujú, a preto možno badat' iniciatívy danú oblast' právne regulovat', na úrovni:

1. OECD,

2. EÚ a

3. jednotlivých štátov.

6 Bližšie: napr. HRABČÁK, L. Výzvy pre daňové právo v podobe Blockchain technológie. In Zborník príspevkov zo 6. ročníka Jarnej internacionalizovanej školy doktorandov UPJŠ 2019, Košice: ŠafárikPress, 2019. s. 160.

BRÖSTL, A. a kol.: Teória práva. Plzeň: Aleš Čeněk, 2013. s. 45.

8 Návrh smernice Rady (EÚ), ktorou sa stanovujú pravidlá týkajúce sa zdaňovania príjmov právnických osôb, ktoré sa vyznačujú významnou digitálnou prítomnost'ou $\{\operatorname{SWD}(2018) 81$ final $\}-\{\operatorname{SWD}(2018) 82$ final $\}$ zo dňa 21.03.2018, čl. 3 ods. 5.

9 Bližšie: napr. BABČÁK, V. Daňové právo na Slovensku. 1. vydanie. Bratislava: EPOS, 2015. s. 39.

10 Bližšie: Dôvodová správa k návrhu smernice Rady (EÚ), ktorou sa stanovujú pravidlá týkajúce sa zdaňovania príjmov právnických osôb, ktoré sa vyznačujú významnou digitálnou prítomnost’ou COM(2018) 147 final zo dňa 21.03.2018. 
Jednotlivým úrovniam prebiehajúcich prác sa budeme venovat' bližšie v d'alších častiach predostretého príspevku. Vo všeobecnosti však štáty či vybrané medzinárodné organizácie uvažujú o troch variantoch riešenia danej otázky, a síce:

1. zachovanie súčasného stavu - tento variant vychádza $z$ toho, že digitálne služby ostatnú nad'alej bez zdanenia,

2. zdaňovanie digitálnych služieb vo verzii DAT (skratka pre digitálnu reklamu) - táto „,verzia“" sa zakladá na zdaňovaní len vybraných digitálnych služieb, a to konkrétne digitálnej reklamy,

3. zdaňovanie digitálnych služieb vo verzii DST (skratka pre digitálne služby všeobecne) predmetný prístup sa v porovnaní so zdaňovaním vo verzii DAT neobmedzuje len na reklamné služby, ale príznačným preň je zdaňovanie digitálnych služieb bez obmedzení.

Jednou z najzávažnejších otázok z pohl'adu vedy o daňovom práve sa stáva nepochybne miesto dane $\mathrm{z}$ digitálnych služieb $\mathrm{v}$ rámci daňových sústav. $Z$ historického hl'adiska je klasifikačné kritérium daní podl'a spôsobu zdaňovania na dane priame a nepriame jedným z najstarších. Rozhodujúcimi aspektmi tohto členenia sú prenos daňového bremena, spôsob ukladania dane a technika výberu dane.

Vo vzt'ahu ku danej otázke nemožno zaujat' jasné stanovisko. I ked' je pravdou, že daň z digitálnych služieb sa môže pretavit' do ceny samotnej služby, čím ju bude znášat' konečný spotrebitel' a dôjde k presunu daňového bremena (napr. Španielsko, ako aj d'alej poukážeme, pracuje s verziou DST ako nepriamou daňou vyňatou spod pôsobnosti zmlúv o zamedzení dvojitého zdanenia), tak na strane druhej sa bude zdaňovat' príjem zo zdanitel'ných služieb. Tým nadobúda táto daň hybridný charakter. Ide o otázku na d’alšiu vedeckú diskusiu.

V texte nižšie poukážeme práve na vybraných príkladoch, aký prístup zvolili vybrané entity a v nadväznosti na to sa pokúsime zhodnotit', aký variant by bol pre štáty, resp. zoskupenia štátov najvhodnejší so zretel'om na predpokladané či reálne výhody a nevýhody.

\section{Medzinárodné a európske nástroje zdaňovania digitálnych služieb}

Vzostup digitálnej ekonomiky prinútil tvorcov politiky, aby sa zaoberali základnými otázkami zdaňovania - ako najlepšie zvýšit’ príjmy na financovanie vládnych výdavkov - v náročnejších súvislostiach. Niektoré vlády pochybovali o primeranosti súčasných daňových režimov, ktorými by mohli nad’alej získavat' dostatočné príjmy. V „Rímskej deklarácii“ z marca 2017, 27 členských štátov Európskej únie, Rada Európskej únie, Európsky parlament a Európska komisia sl'úbili, že sa budú usilovat’ o technologickú transformáciu, ktorá je nevyhnutným prvkom na zabezpečenie prosperujúcej a udržatel’nej budúcnosti. ${ }^{11} \mathrm{~V}$ skutočnosti technologická transformácia a digitalizácia hlboko ovplyvňujú vel'ké množstvo zamestnancov - pracovné miesta, priemyselné odvetvia, vzdelávanie a systémy sociálneho zabezpečenia. Zároveň však vytvárajú výzvy pre existujúce daňové systémy. Nové obchodné modely tzv. digitálnej ekonomiky sú založené na moderných informačných a komunikačných technológiách a využívaní vel'kého množstva údajov, ktoré často rozmazávajú čiary medzi tovarom a službami a líšia sa ich prístupom, formou, dopadom a speňažením (napr. online maloobchodníci, platformy sociálnych médií, predplatné digitálnych služieb a platformy spolupráce).

Tvorcovia politík, vrátane tvorcov politík EÚ, sa snažia nájst’ riešenia, ktoré by zabezpečili spravodlivé a efektívne zdaňovanie, z dôvodu zrýchl'ujúcej sa digitálnej transformácie hospodárstva. Tvrdia, že v stávke nie je nič iné ako globálna resp. hospodárska prosperita, ako aj daňová spravodlivost' a suverenita. Debaty týkajúce sa „vhodnosti““ alebo „zastaralosti““ súčasného medzinárodného daňového systému v digitálnom veku teda výrazne prekrývajú dis-

11 Deklarácia vedúcich predstavitel’ov 27 členských štátov a Európskej rady, Európskeho parlamentu a Európskej komisie. Viac pozri Rímska deklarácia z 27.03.2017. [cit. 12-12-2019]. Dostupné na:

https://ec.europa.eu/slovakia/news/rome declaration2017 sk. 
kusie o praktikách vyhýbania sa daňovým povinnostiam a agresívnych postupov daňového plánovania známych technologických spoločností. OECD a EÚ pôsobivo načrtli rôzne nové obchodné modely, ich rast, vel'kost' a vplyv na svetové hospodárstvo, ako aj rozdiely v daňovom zat’ažení medzi spoločnost’ami, ktoré ponúkajú klasické cezhraničné fyzické služby, a spoločnost'ami, ktoré ponúkajú digitálne služby. ${ }^{12}$ Vzhl'adom na všadeprítomný charakter digitalizácie však môže byt' t’ažké, ak nie nemožné, odstrihnút' digitálnu ekonomiku od zvyšku ekonomiky na daňové účely. Niektorí argumentujú, že osobitné zdaňovanie založené na digitálnej prítomnosti by samo osebe neviedlo k porušeniu zásady neutrality, d'alší zastávajú opačný názor. Nové obchodné modely okrem týchto výziev v oblasti priamych a nepriamych daní vyvolávajú aj množstvo d'alších otázok súvisiacich s daňami a s ich mobilitou a dematerializáciou, medzi nimi aj potenciál na zníženie schopnosti štátov vyberat' príjmy z daní zo mzdy, environmentálnych daní, daní z nehnutel'ností a daní z majetku.

OECD a EÚ otvárajú "Pandorinu skrinku", kde digitálny sektor predstavuje iba jeden z hlavných problémov, ktorý už nie je možné udržat' v škatul'ke. V akademickej literatúre je revízia digitálneho sektora novou príležitost’ou na diskusiu o celej štruktúre medzinárodného daňového systému. Zdá sa, že akademici, niektoré štáty, EÚ a inkluzívny rámec OECD čoraz viac súhlasia so štrukturálnym nedostatkom súčasného medzinárodného daňového systému. Zdá sa však, že sa všetci na riešení nezhodujú - aspoň pokial' ide o dlhodobé riešenie.

\subsection{OECD a DST}

Digitálna transformácia hospodárstva spochybňuje, či medzinárodné daňové pravidlá, ktoré sa do značnej miery zaviedli počas posledných 100 rokov, zostávajú v modernej globálnej ekonomike zmysluplné. Aj ked' sa v rámci projektu BEPS dosiahol dobrý pokrok v boji proti erózii bázy a presunu zisku (BEPS), niektoré z problémov, ktoré digitalizácia predstavuje, sa neriešili. $\mathrm{V}$ rámci projektu BEPS a nedávno prostredníctvom inkluzívneho rámca pre BEPS prebiehajú diskusie o tom, ako riešit' daňové problémy, ktoré vznikajú v dôsledku digitalizácie. Nedávne medzinárodné úsilie o riešenie týchto otázok poukázalo na rozdielne postoje mnohých jurisdikcií. Aj ked' zavedenie jednostranných opatrení vo viacerých krajinách podčiarklo naliehavost' problému a potrebu prehodnotit' niektoré z kl'účových medzinárodných daňových zásad, tieto rozdielne stanoviská st'ažili dosiahnutie riešenia založeného na konsenze.

Politická poznámka OECD z 23. januára $2019^{13}$ a konzultačný dokument z 13.februára až 6. marca $2019^{14}$ potvrdili, že OECD sa sústredí na dve oblasti (d’alej len „dva,, piliere “). Pilier 1 sa zameriava na pridel'ovanie práv na zdanenie a snaží sa o koherentné a súbežné preskúmanie pravidiel pridel'ovania zisku a vzájomných vzt’ahov. Tri návrhy, o ktorých sa uvažuje v rámci prvého piliera sa zameriavajú nad rámec existujúcich konceptov medzinárodného daňového rámca, ktoré si vyžadujú fyzickú prítomnost' na účely zdaňovania práv a pridel'ovania zisku resp. strát podl'a zásady trhovej nezávislosti (Návrh „účast' použivatel’ov, Návrh „,nehmotného marketingu“ a Návrh „významnej hospodárskej pritomnosti“). Pilier 2 sa zameriava na vypracovanie pravidiel proti globálnemu narúšaniu základu (skrátene označené GloBE z angl. slov Global Anti - Base Erosion), ktoré sa zameriava na zostávajúce problémy

12 Pozri napr. e.g. Eur. Comm'n, Report of the Commission Expert Group on Taxation of the Digital Economy (Eur. Union 28 May 2014) (Commission Expert Group on Taxation of the Digital Economy); OECD, Addressing the Tax Challenges of the Digital Economy, Action 1-2015 Final Report, OECD/G20 Base Erosion and Profit Shifting Project (OECD Publishing 2015) (2015 OECD BEPS Action 1 Report), and OECD, Tax Challenges Arising from Digitalisation - Interim Report 2018: Inclusive Framework on BEPS (OECD Publishing 2018) (2018 OECD BEPS Interim Report).

13 Viac pozri: OECD: Addressing the Tax Challenges of the Digitalisation of the Economy - Policy Note. As approved by the Inclusive Framework on BEPS on 23 January 2019.

14 Pozri: OECD. Public Consultation Document. ADDRESSING THE TAX CHALLENGES OF THE DIGITALISATION OF THE ECONOMY 13 February - 6 March 2019. 
BEPS a snaží sa vyvinút' pravidlá, ktoré by jurisdikciám poskytli právo na „vrátenie daní“, ak iné jurisdikcie nevykonali svoje primárne daňové práva alebo ak platba inak podlieha nízkej úrovni skutočného zdanenia. ${ }^{15}$

Vo významnom predstihu sa 128 členov inkluzívneho rámca nedávno dohodlo na politickej poznámke- „Riešenie daňových výziev vyplývajúcich z digitalizácie“ (OECD, 2019a) ktorá identifikuje konkrétne návrhy v dvoch pilieroch, ktoré treba preskúmat' a ktoré by mohli tvorit' základ globálne riešenie založené na konsenze. Tieto piliere zahŕňajú prerozdelenie daňových práv medzi jurisdikciami a potrebu riešit' zostávajúce problémy BEPS. Práca v oblasti daní a digitalizácie je kl'účovým aspektom projektu BEPS od jeho vzniku. V Akcii 1, ktorá bola uverejnená ako súčast' balíka BEPS v októbri 2015, sa zistilo, že v dôsledku všadeprítomnej povahy digitalizácie by bolo t’ažké, ak nie nemožné, vyčlenit' „digitálnu ekonomiku“ od zvyšku hospodárstva na daňové účely. Inými slovami, krajiny sa zhodli na tom, že nejde o „digitálnu ekonomiku“, ale o to, že samotná ekonomika sa digitalizovala a že tento trend bude pravdepodobne pokračovat'.

Dôležitou súčast'ou práce OECD v budúcnosti bude najmä revízia medzinárodných daňových pravidiel s ohl'adom na vplyv digitalizácie, ktorá má dôležité dôsledky pre nadnárodné spoločnosti a vlády, ako aj budúcnost' našich daňových systémov. Aktualizácia práce OECD v týchto oblastiach bude súčast'ou správy o daniach a digitalizácii, ktorá pripraví inkluzívny rámec, ktorý bude predložený skupine G20 v roku 2020. ${ }^{16}$

\subsection{Európska únia a DST}

Jednou z úrovní, na ktorej prebiehajú práce v súvislosti so zdaňovaním digitálnych služieb, je aj EÚ. Predstavitelia inštitúcií EÚ si uvedomujú tú skutočnost', že v čoraz väčšej miere dochádza k využívaniu podnikatel'ských modelov na digitálnej báze, ktoré predstavujú odklon od modelov založených na fyzickej prítomnosti, vo vzt’ahu ku ktorým je uplatňovaná daňová suverenita členských štátov. ${ }^{17}$

Je teda faktom, že vel'ká čast' ziskov tak v súčasnosti nepodlieha zdaneniu, resp. je zdaňovaná iba v minimálnej miere. Podl'a nášho názoru však nemožno hovorit' o daňových únikoch, pretože oň môže íst' iba vtedy, ak daňová povinnost' existuje. Inak povedané, ak daňové systémy členských štátov neviažu na digitálne služby aj povinnost' platit' daň, nemôže íst' o daňový únik. ${ }^{18}$

Už 29. septembra 2017 sa uskutočnil Digitálny samit v Talline, ktorý bol zorganizovaný predsedníctvom Rady v spolupráci s Európskou komisiou a taktiež predsedom Európskej rady. Pokial' ide o účast', tak samitu sa zúčastnili hlavy členských štátov a predsedovia vlád členských štátov. Ciel'om samitu bolo vytvorit' akúsi platformu pre budúce diskusie ohl'adom digitálnych inovácii, čo má EÚ zabezpečit' konkurencieschopnost' v globálnom meradle s ostatnými svetovými mocnost'ami.

Ďalšie iniciatívy EÚ v danej oblasti pokračovali v októbri roku 2017. V dokumente označenom ako „Závery Európskej rady, 19.10.2017“, ktorý bol výsledkom zasadnutia reprezentantov členských štátov, boli prijaté viaceré závery, a to konkrétne aj o otázke „Digitálna Európa“. V rámci tohto bodu určila Európska rada viaceré priority, jednou z ktorých bolo ,,do-

15 BHOGAL, S. et al. European Union: Taxing The Digital Economy And Digital Service Tax Proposals Impacting The United Kingdom And The European Union. 2019. [online]. [cit. 29-12-2019]. Dostupné na: http://www.mondaq.com/uk/x/821258/withholding+tax/Taxing+The+Digital+Economy+And+Digital+Service+Tax+ Proposa ls+Impacting+The+United+Kingdom+And+The+European+Union .

16 OECD (2019), "Tax and Digitalisation", OECD Going Digital Policy Note, OECD, Paris. [online]. [cit. 29-12-2019]. Dostupné na: http://www.oecd.org/tax/beps/tax-and-digitalisation.pdf.

17 Pojem “členské štáty” na účely tohto článku používame v ponímaní členských štátov EÚ.

18 Porovnaj: Európska komisia: Zdaňovanie digitálneho hospodárstva. [online]. [cit. 24-12-2019]. Dostupné na: https://www.consilium.europa.eu/sk/policies/digital-taxation/. 
siahnutie efektívneho a spravodlivého systému zdaňovania, ktorý bude vyhovovat' potrebám digitálneho veku. "19

Následne, dňa 5. decembra 2017 schválila Rada príspevok k medzinárodnej diskusii. Rada rokovala o otázke, akou je zdaňovanie ziskov v digitálnom hospodárstve a vyzvala zároveň na úzku spoluprácu s OECD a inými partnermi na medzinárodnej úrovni.

V marci roku 2018 už Európska komisia predložila 2 legislatívne návrhy:

1. návrh smernice DST a

2. návrh smernice Rady (EÚ) o spoločnom systéme zdanenia digitálnych služieb formou dane z výnosov z poskytovania určitých digitálnych služieb.

Kým v prvom rade sa ráta s tým, že ide o trvalé riešenie, tak druhá spomínaná smernica má byt' len akýmsi dočasným a kompromisným riešením smerujúcim k trvalej regulácii právnych vzt'ahov v predmetnej oblasti.

Aj napriek tomu, že členské štáty sa zhodujú v tom, že daňové predpisy sú už zastaralé, tak do dnešného dňa nedošlo ku konsenzu. Rovnako to platí o kompromisnom návrhu zo strany Nemecka a Francúzska, ktorý sa týkal zdaňovania digitálnej reklamy (DAT).

Treba však dodat', že zdanitel'nou osobou by nebola akákol'vek právnická osoba, čím chcela Komisia zámerne „odbremenit““ od takejto dane malé a stredné podniky, ktoré sú označované ako hnací motor digitálnej ekonomiky. Zdanitel'nou osobou by tak boli iba digitálni giganti ako napr. Google, Apple, Facebook, príp. iné spoločnosti, ktorých ročný obrat presiahne 750 miliónov eur a dosahujú zdanitel'né príjmy nad 50 miliónov eur v rámci EÚ. Navrhovaná je daňová sadzba vo výške $3 \%$.

V súvislosti s vyššie načrtnutými iniciatívami vyvstávajú viaceré d’alšie otázky. Jednou z nich je to, či EÚ si týmito návrhmi nechce vytvorit’ lepšiu pozíciu pri harmonizácii korporátnej dane. Tieto snahy pri prenikaní harmonizačných prvkov do oblasti priameho zdaňovania bolo možné badat' aj pri smernici ATAD.

\section{Vnútroštátne modely zdaňovania digitálnych služieb}

\subsection{Perspektívy zdaňovania digitálnych služieb v Slovenskej republike}

Právny poriadok Slovenskej republiky reflektuje $\mathrm{v}$ súčasnosti len na niektoré javy $\mathrm{v}$ digitálnej ekonomike. Patrí medzi ne zdaňovanie virtuálnych mien ${ }^{20}$ a zdaňovanie zdiel'anej ekonomiky ${ }^{21}$. Naša právna úprava teda za súčasného stavu nereguluje zdaňovanie digitálnych služieb.

Možno konštatovat', že i ked' slovenské daňové právo reflektuje na niektoré prvky digitálnej ekonomiky (vid' vyššie), tak ide len o riešenia, ktoré nemajú komplexný charakter. Nedochádza tu k zavádzaniu nových daní, ale ide o zdaňovanie prostredníctvom už existujúcich konkrétne dani z príjmov novelizáciami zákona č. 595/2003 Z. z. o dani z príjmov v znení neskorších predpisov. Efektivita týchto nástrojov je taktiež otázna.

Ministerstvo financií Slovenskej republiky nateraz deklaruje, že neuvažuje o zavedení národnej dane z digitálnych služieb, ale čaká na komplexné a harmonizované riešenie na úniovej úrovni, a to nielen čo sa týka dane z digitálnych služieb vo verzii DST, ale aj kompromisu vo verzii DAT (teda len digitálnej reklamy). ${ }^{22}$

19 Európska komisia: Európska rada, 19. - 20. októbra 2017. [online]. [cit. 24-12-2019]. Dostupné na: https://www.consilium.europa.eu/sk/meetings/european-council/2017/10/19-20/.

20 Bližšie: HRABČÁK, L. „Virtuálna mena“ a právo. In Vplyv moderných technológii na právo: recenzovaný zborník prispevkov z vedeckej konferencie. Košice: Univerzita Pavla Jozefa Šafárika v Košiciach, 2019. s. 99 - 110.

21 Bližšie: BONK, F. O zdaňovaní príjmov v kontextoch zdiel'anej ekonomiky. In. Justičná revue, roč. 70, 2018, č. 12, s. 1342 - 1356

22 Bližšie: EURACTIV. Štáty Únie sa na digitálnej dani nedohodli, krajiny V4 plánujú konat' na vlastnú päst'. [online]. [cit. 24-12-2019]. Dostupné na: https://euractiv.sk/section/buducnost-eu/news/staty-unie-sa-na-digitalnej-dani-nedohodlikrajiny-v4-planuju-konat-na-vlastnu-past/. 
Postoj Slovenskej republiky možno hodnotit' určite kladne, pretože s ,digitálnou daňou“ (tak ako ju niektorí autori označujú skrátene) sú spojené určité otázky najmä vo vzt’ahu ku jednotnému trhu a slobodám k nemu prislúchajúcim. Ked’že niektoré členské štáty (vid' nižšie) už daň z digitálnych služieb zaviedli, možno teda očakávat', že aj jej základné parametre a určité „mantinely“ toho, aby išlo o inštitút súladný s právom EÚ, judikuje Súdny dvor EÚ.

\section{2. Česká republika a návrh tzv. zákona o digitálnej dani}

I ked’ Česká republika je jedným zo susedných štátov Slovenskej republiky, situácia v oblasti zdaňovania je odlišná, čo sa prejavuje aj v otázke zdaňovania digitálnych služieb. Momentálne ani v Česku však nie je zavedená digitálna daň, avšak Ministerstvo financií Českej republiky predložilo „Návrh zákona o dani z vybraných digitálních služeb “. Podl'a nášho názoru ide však o nesprávne označenie so zretel'om aj na to, že predkladatel' zákona v rámci dôvodovej správy sám uvádza, že sa priklonil k variantu zdaňovania digitálnych služieb vo verzii DST a nie len DAT. ${ }^{23}$ Preto by z označenia predmetného právneho predpisu malo byt' vypustené slovo „vybraných“, aby to korešpondovalo legislatívnemu zámeru.

Ministerstvo financií Českej republiky pracovalo teda so všetkými variantami, ktoré prichádzali do úvahy, pričom pri hl'adaní najvhodnejšieho riešenia hodnotilo ich predpokladané výhody a nevýhody. Základnými hodnotiacimi kritériami boli:

- „narovnanie“ podnikatel’ského prostredia,

- daňový výnos a

- administratívne náklady.

Daň z digitálnych služieb vo verzii DST sa tak podl'a predkladatel'a javí ako najvhodnejší spôsob, akým zdanit' digitálne služby so zretel'om na uvedené kritéria. Je nutné podotknút', že návrh zákona vychádza vo vel'kej miere z návrhu smernice DST, čomu zodpovedá aj daňová sadzba 3\%a rovnako vymedzenie zdanitel'ných osôb.

Ako primárny ciel' sa deklaruje narovnanie podnikatel'ského prostredia medzi spoločnost’ami založenými na „tradičných modeloch“ a spoločnost'ami založenými na tzv. „digitálnych modeloch“. Až ako sekundárny ciel’ sa deklaruje daňový výnos z tejto navrhovanej dane. Podl'a nášho názoru však predkladatel' zastiera to, že práve primárnym ciel'om je daňový výnos, čo možno demonštrovat' aj na tom, že i ked' by došlo k narovnaniu podnikatel'ského prostredia v Česku, v kontexte EÚ by sa vytvorili disproporcie na jednotnom vnútornom trhu a došlo by k nerovnému postaveniu podnikatel'ov, ktorí využívajú, resp. sa zakladajú na digitálnych modeloch podnikania.

Daňový výnos digitálnej dane vo verzii DST sa odhaduje v rozmedzí od cca 2,4 mld. až 6,6 mld. Kč ročne. Reálne sa odhaduje výnos v polovici uvedeného intervalu, t. j. vo výške cca 5 mld. Kč. Išlo by teda o daň, ktorá má významný rozpočtovo - právny význam.

Nemenej významnou otázkou/kritériom sú aj administratívne náklady. Administratívnu zát'až je potrebné hodnotit' v dvoch smeroch, a to nielen vo vzt'ahu ku štátu, ale aj vo vzt'ahu ku daňovým subjektom. Pre štát by malo íst' o jednorazové náklady vo výške cca 23,5 mil. Kč a požiadavky na personálny substrát správcov dane. Náklady na strane daňových subjektov vzniknú taktiež. Ministerstvo financií Českej republiky uvádza, že budú minimálne, pričom argumentuje osobným rozsahom predmetnej dane - vel'ké konglomeráty, ktoré sú vybavené administratívnym a účtovným aparátom.

V súvislosti s navrhovanou právnou úpravou boli identifikované aj viaceré riziká. Tým azda najväčším je prenos dane do výšky cien zdanitel'ných služieb. Obavy sú najmä v tom, že daňové bremeno ponesú spotrebitelia. Vo vzt’ahu k tomu sa žiada dodat', že daň z digitálnych

23 Okrem realizácie cielenej reklamnej kampane sú podl’a návrhu zákona zdanitel’nými službami aj využívanie mnohostranného digitálneho rozhrania a predaj dát o užívatel'och. 
služieb sa nemusí prejavit' len vo vzt'ahu ku cenám konečných spotrebitel'ov, ale aj v rámci cien napr. voči objednávatel’om cielených reklám. Z návrhu zákona a dôvodovej správy nevyplýva či ide o priamu alebo nepriamu daň, no so zretel'om na uvedené, pôjde pravdepodobne o nepriamu daň.

Česká republika sa tak rozhodla íst' cestou unilaterálneho riešenia daného problému, čo nie je určite koncepčný prístup. Ide tu však len o akési „dočasné“ opatrenie do momentu očakávaného konsenzu na úrovni EÚ či OECD.

\subsection{Iné (vybrané) štáty a zdaňovanie digitálnych služieb}

Už niekol'ko rokov sa na medzinárodnej úrovni, na úrovni EÚ a na vnútroštátnej úrovni vyvíja úsilie o reformu zdaňovania s ciel'om zabezpečit', aby sa zisky zdaňovali tam, kde sa vytvára hospodárska hodnota. Táto práca sa $\mathrm{v}$ poslednom čase sústredí na digitálnu ekonomiku, avšak táto skutočnost' má korene v skúmaní stratégií daňového plánovania, ktoré využívajú nadnárodné spoločnosti pôsobiace vo viacerých jurisdikciách. Niekol'ko štátov zobralo zavedenie vlastných iniciatív týkajúcich sa vnútroštátnych daní pre digitálne spoločnosti „do vlastných rúk“, pričom tieto iniciatívy obsahujú „doložky o ukončení platnosti“ a ich platnost’ sa skončí vtedy, ak sa dosiahne dohoda na medzinárodnej úrovni alebo na úrovni EÚ. Nedávny vývoj nastal v daňových systémoch v Rakúsku, Belgicku, Českej republike, Francúzsku, Mad'arsku, Taliansku, Pol'sku, Slovinsku, Španielsku a Spojenom král'ovstve. Niektoré tieto krajiny navrhli, oznámili alebo už implementovali určitú formu dane z digitálnych služieb, ktoré si v skratke rozoberieme nižšie.

\section{FRANCÚZSKO}

Francúzsko je prvým členským štátom EÚ, ktorý zaviedol daň z digitálnych služieb (DST). „Daň 21. storočia” je platná od 1. januára 2019. DST bola nazvaná ako „daň GAFA“ (skratka hlavných amerických ciel'ov: Google, Apple, Facebook a Amazon). Na rozdiel od toho, čo naznačuje táto skratka, francúzska daň GAFA sa však nezameriava iba na americké skupiny, ale aj na iné medzinárodné skupiny vrátane francúzskych, čínskych, nemeckých španielskych a anglických skupín. Francúzska daňová správa odhadla, že táto daň by mohla mat' vplyv na približne 30 medzinárodných skupín. Francúzska DST, podobne ako návrh EÚ DST, sa zameriava na dve kategórie služieb, v ktorých sú dominantné americké spoločnosti - internetová reklama a „digitálne rozhrania“, ktoré sa vzt'ahujú na online trhy s tovarom a službami a niektoré predplatné služby ako zoznamovacie webové stránky.

Francúzska DST ukladá 3\% daň z príjmov vytvorených z dvoch kategórií „,zdanitel'ných služieb“: 1. „služby digitálneho rozhrania“ a 2. „,cielené reklamné služby“. DST sa uplatňuje iba na príjmy, ktoré sa považujú za získané z poskytovania takýchto služieb „vo Francúzsku“, a zákon poskytuje usmernenie o tom, ako spoločnosti musia vypočítat' podiel na svojich globálnych príjmoch pripadajúci Francúzsku. DST sa vzt’ahuje iba na spoločnosti, ktoré spíňajú globálne a francúzske limity príjmov pre pokryté služby. ${ }^{24}$

Dodávka digitálnej platformy sa týka umiestnenia používatel'ov. Ak sa jeden z používatel'ov platformy nachádza v príslušnom daňovom roku vo Francúzsku, služba sa bude považovat' za poskytnutú vo Francúzsku. Francúzska daň GAFA sa nevzt'ahuje na platformy, pre ktoré zhromažd'ovanie údajov používatel'ov nie je hlavným ciel'om. Ak podniky v zásade používajú digitálne rozhranie na poskytovanie nasledujúcich služieb používatel'om, dodávka digitálnej platformy by nemala byt' zdanitel'ná:

24 Office of the United States Trade Representative Ambassador Robert E. Lighthizer. Report on France's Digital Services Tax Prepared in the Investigation under Section 301 of the Trade Act of 1974. [online]. [cit. 15-12-2019]. Dostupné z: https://ustr.gov/sites/default/files/Report_On_France\%27s_Digital_Services_Tax.pdf. 
1. digitálny obsah, ako je elektronický obchod, video služby, hudba na požiadanie,

2. komunikačné služby,

3. regulované platobné služby. ${ }^{25}$

Daň GAFA na to, aby sa mohla uplatňovat' musí spíňat' dve kritéria, a to: celosvetový ročný obrat 750 miliónov EUR v prípade digitálnych služieb a domáci obrat 25 miliónov EUR v oblasti digitálnych služieb lokalizovaných vo Francúzsku. Francúzsko, tak ako bolo uvedené vyššie, prijalo sadzbu navrhovanú v návrhoch EÚ a uplatnilo $3 \%$ daň z príjmov pochádzajúcich z akýchkol'vek digitálnych služieb, ktoré splńajú vyššie uvedené kritériá, pričom za platitel'a sa považuje spoločnost', ktorá dostáva platbu za príslušné digitálne služby. Základ dane bude preto závisiet' od toho, aká čast' platieb sa týka Francúzska, d’alej od druhu služieb a od druhu platformy.

Uvalením dane z digitálnych služieb (GAFA) sa predpokladá, že štátny rozpočet Francúzska vzrastie o 600 mil. EUR ročne.

\section{ŠPANIELSKO}

Španielska vláda pripravila návrh rámcového zákona, ktorý sa líši od európskeho návrhu. Oproti Francúzsku, španielska vláda predpokladá nárast príjmov z DST až vo výške 1200 mil. EUR ročne.

Hlavnými črtami tohto návrhu zákona sú:

1. DST sa považuje za nepriamu daň a preto sa na ňu neuplatňujú zmluvy o zamedzení dvojitého zdanenia,

2. subjekty musia spíňat' nasledujúce kritéria: čisté príjmy za predchádzajúci kalendárny rok musia presahovat' 750 mil. EUR a zároveň celková hodnota výnosov získaných z rozvoja činností, ktoré podliehajú DST v Španielsku musia presiahnut' 3 mil. EUR.

Medzi príjmy, ktoré sú zdaňované daňou z digitálnych služieb patria:

1. online reklamné služby,

2. služby prenosu údajov,

3. sprostredkovatel'ské služby.

Základom dane sú celkové príjmy získané z vyššie uvedených činností, bez DPH, pričom sadzba dane sa ustanovila rovnako ako vo Francúzsku vo výške $3 \%$.

\section{SPOJENÉ KRÁLOVSTVO}

V júli 2019 britská vláda uverejnila svoj finančný návrh zákona 2019-20, ktorý obsahoval návrh právnych predpisov týkajúcich sa dane z digitálnych služieb vo výške $2 \%$, pokial' ide o príjmy z: vyhl'adávacích nástrojov, platforiem sociálnych médií a online trhovísk (finančné a platobné služby sú oslobodené) bez ohl'adu na to, ako speňažujú svoje platformy. DST by sa v Spojenom král'ovstve mala uplatňovat' od apríla 2020 a predpokladá sa, že sa takto zvýšia príjmy krajiny v prvom roku o 275 mil. GBP a následne o 370 mil. GBP. DST sa bude vzt'ahovat' iba na skupiny s globálnymi príjmami nad 500 mil. GBP a príjmami Spojeného král'ovstva nad 25 mil. GBP, čo zahŕňa príspevok, takže prvých 25 mil. GBP príjmov od používatel'ov vo Vel'kej Británii nebude podliehat' DST. ${ }^{26}$

\section{POLSKO}

Iniciatívy zavedenia DST prebiehali aj u nášho severného suseda, avšak zatial’ neúspešne. Začiatkom marca 2019 kancelária predsedu vlády oznámila, že pol'ský rozpočet bude mat'

25 DORIN, S. Digital Services Tax in France. [online]. [cit. 15-12-2019]. Dostupné na: https://www.twobirds.com/en/news/articles/2019/global/digital-services-tax-in-france.

26 GOUGH, S. Digital Services Tax in the UK. [online]. [cit. 15-12-2019]. Dostupné na: https://www.twobirds.com/en/news/articles/2019/global/digital-services-tax-in-the-uk. 
prospech zo zavedenia digitálnej dane s predpokladanou hodnotou cca. 1 miliarda PLN ročne. V máji však ministerstvo financií odložilo d’alšie oznámenie na tento účel. V júli ministerstvo financií oznámilo, že pracuje na návrhu zákona o zdaňovaní určitých digitálnych služieb, ktorého východiskovým bodom by mal byt' návrh smernice ES prijatý v marci 2019. Po schválení návrhu rozpočtu na nasledujúci kalendárny rok, v ktorom absentovala digitálna daň a jej výber sa Pol'sko vyhradilo k tomu, že v budúcnosti sa DST bude uplatňovat', avšak zatial' sa ministerstvo bude nad'alej zapájat' do diskusií na fórach EÚ a OECD a bude čakat' na iniciatívy z prostredia EÚ. Teraz sa však predpokladá, že DST sa v Pol'sku bude uplatňovat' na: príjmy z online reklamy, predaja údajov získaných z informácií poskytnutých používatel'om a $\mathrm{z}$ iných digitálnych služieb a určí sa vo výške $3 \%$ ako to vyplýva z návrhu EÚ. ${ }^{27}$

\section{ZÁVER}

V predostretom príspevku sme si vytýčili ako hlavný ciel' rozanalyzovat' vybrané aspekty digitálnej ekonomiky, a to najmä zdaňovanie digitálnych služieb a načrtnút' možné d’alšie tendencie smerom do budúcna za súčasného overenia nastolených hypotéz.

Bez nároku na úplnost' sme sa snažili poskytnút' stručný exkurz vybraným aspektom digitálnej ekonomiky - zdaňovania digitálnych služieb, a to nielen v podmienkach Slovenskej republiky, ale aj iných štátoch, pričom neopomenuli sme ani navrhované právne úpravy na medzinárodnej úrovni (EÚ a OECD).

Nosnou hypotézou, ktorú sme si v úvode článku stanovili overit', bolo - či digitálne služby sa majú zdaňovat'. Táto hypotéza sa nám potvrdila, a preto môžeme konštatovat', že digitálne služby by sa mali zdaňovat', a to odhliadnuc od toho, že sa zastiera primárny ciel' (rozpočtovo - právny význam) navrhovanej právnej úpravy zrovnoprávnením podnikatel’ov podnikajúcich na tradičnej báze a podnikatel'ov využívajúcich digitálne modely. Z nášho uhla pohl'adu je najdôležitejší rozpočtový význam, ked’že Európska komisia odhaduje, že členské štáty by mohli získat' príjmy až vo výške 5 miliárd eur ročne. Otáznejšie je to, ako to dosiahnut', a preto sme pokračovali v overovaní d'alších, čiastkových hypotéz.

Taktiež musíme konštatovat', že existujúce nástroje zdaňovania nepostačujú na zdaňovanie príjmov z digitálnych služieb a je preto potrebné zaviest' novú daň, ktorá by sa zakladala na princípe zdaňovania $\mathrm{v}$ mieste, kde sa hodnota a zisk skutočne generujú. Ide teda o odklon od tradičného zdaňovania založeného na fyzickej prítomnosti subjektu na konkrétnom mieste.

Ked’že súčasné nástroje zdaňovania nepostačujú na zdaňovanie digitálnych služieb, nastolili sme d’alšie hypotézy s tým súvisiace, a síce či je potrebné nájst' medzinárodný, či európsky model zdaňovania alebo bude vhodnejšie ponechat' zdaňovanie digitálnych služieb v daňovej suverenite jednotlivých štátov. So zretel'om na to, že v rámci EÚ je vybudovaný jednotný vnútorný trh a slobody s tým súvisiace, sme toho názoru, že je potrebné hl'adat' aspoň európsky model zdaňovania digitálnych služieb.

Jedným dychom však treba dodat', že momentálne nie je možné dosiahnut' konsenzus na úrovni EÚ, a preto reálnejšími sa zdajú byt' unilaterálne právne úpravy, čo bude zaujímavé aj $\mathrm{z}$ toho hl'adiska, aké stanovisko k tomu zaujme Súdny dvor EÚ.

Spracovaná problematika predstavuje len úvod do diskusie, pretože len tou možno dospiet' k efektívnemu riešeniu zdaňovania digitálnych služieb, ktorých význam a rozsah bude narastat' vo svete digitálnej ekonomiky aj nad'alej.

\section{KLÚČOVÉ SLOVÁ}

Digitálna ekonomika, digitálne služby, daň.

27 SIKORA, B. Digital Services Tax in Poland. [online]. [cit. 15-12-2019]. Dostupné na: https://www.twobirds.com/en/news/articles/2019/poland/digital-services-tax-in-poland. 


\section{KEY WORDS}

Digital Economy, Digital services, Tax.

\section{POUŽITÁ LITERATÚRA}

1. BABČÁK, V. Daňové právo na Slovensku. 1. vydanie. Bratislava: EPOS, 2015. 750 s. ISBN 978-80-562-0091-9.

2. BHOGAL, S. et al. European Union: Taxing The Digital Economy And Digital Service Tax Proposals Impacting The United Kingdom And The European Union. 2019. [online]. [cit. 29-12-2019]. Dostupné na:

http://www.mondaq.com/uk/x/821258/withholding+tax/Taxing+The+Digital+Economy+ And + Digital + Service + Tax + Proposals + Impacting + The + United + Kingdom + And + The + Eur opean+Union.

3. BONK, F. O zdaňovaní príjmov v kontextoch zdiel'anej ekonomiky. In Justičná revue, roč. 70, 2018, č. 12, s. 1342 - 1356.

4. BRÖSTL, A. a kol.: Teória práva. Plzeň: Aleš Čeněk, 2013. s. 45. ISBN 978-80-7380425-1.

5. DORIN, S. Digital Services Tax in France. [online]. [cit. 15-12-2019]. Dostupné na: https://www.twobirds.com/en/news/articles/2019/global/digital-services-tax-in-france.

6. EURACTIV. Štáty Únie sa na digitálnej dani nedohodli, krajiny V4 plánujú konat' na vlastnú päst'. [online]. [cit. 24-12-2019]. Dostupné na:

https://euractiv.sk/section/buducnost-eu/news/staty-unie-sa-na-digitalnej-dani-nedohodlikrajiny-v4-planuju-konat-na-vlastnu-past/.

7. Európska komisia: Zdaňovanie digitálneho hospodárstva. [online]. [cit. 24-12-2019]. Dostupné na: https://www.consilium.europa.eu/sk/policies/digital-taxation/.

8. Európska komisia: Európska rada, 19. - 20. októbra 2017. [online]. [cit. 24-12-2019]. Dostupné na:

https://www.consilium.europa.eu/sk/meetings/european-council/2017/10/19-20/.

9. GOUGH, S. Digital Services Tax in the UK. [online]. [cit. 15-12-2019]. Dostupné na: https://www.twobirds.com/en/news/articles/2019/global/digital-services-tax-in-the-uk.

10. HRABČÁK, L. Výzvy pre daňové právo v podobe Blockchain technológie. In Zborník príspevkov zo 6. ročníka Jarnej internacionalizovanej školy doktorandov UPJŠ 2019. Košice: ŠafárikPress, 2019. 250 s. ISBN 978-80-8152-741-8.

11. HRABČÁK, L. „Virtuálna mena“ a právo. In Vplyv moderných technológii na právo: recenzovaný zbornik príspevkov z vedeckej konferencie. Košice: Univerzita Pavla Jozefa Šafárika v Košiciach, 2019. 310 s. ISBN 978-80-8152-728-9.

12. OECD (2019), "Tax and Digitalisation", OECD Going Digital Policy Note, OECD, Paris. [online]. [cit. 29-12-2019]. Dostupné na: http://www.oecd.org/tax/beps/tax-anddigitalisation.pdf.

13. Office of the United States Trade Representative Ambassador Robert E. Lighthizer. Report on France's Digital Services Tax Prepared in the Investigation under Section 301 of the Trade Act of 1974. [online]. [cit. 15-12-2019]. Dostupné na:

https://ustr.gov/sites/default/files/Report_On_France\%27s_Digital_Services_Tax.pdf.

14. PAPULA, J. a kol. Manažérska ekonomika. 1. vydanie. Bratislava: Wolters Kluwer, 2017. 258 s. ISBN 978-80-7552-808-7. 
15. SIKORA, B. Digital Services Tax in Poland. [online]. [cit. 15-12-2019]. Dostupné na: https://www.twobirds.com/en/news/articles/2019/poland/digital-services-tax-in-poland.

\section{KONTAKTNÉ ÚDAJE AUTOROV}

Mgr. Ladislav Hrabčák

Interný doktorand

UPJŠ v Košiciach, Právnická fakulta

Katedra finančného práva, daňového práva a ekonómie

E-mail: ladislav.hrabcak@student.upjs.sk

\section{JUDr. Monika Stojáková}

Interná doktorandka

UPJŠ v Košiciach, Právnická fakulta

Katedra finančného práva, daňového práva a ekonómie

E-mail: monika.stojakova@student.upjs.sk 